\title{
Cu-, Pb- és Cd-adszorpció hatása a talajmontmorillonit kristályszerkezetére és szerkezeti duzzadására
}

\author{
${ }^{1}$ NÉMETH TIBOR, ${ }^{1}$ SIPOS PÉTER, ${ }^{1}$ TÓTH MÁRIA és ${ }^{2}$ MOHAI ILONA \\ ${ }^{1}$ MTA Geokémiai Kutatóintézet, Budapest és \\ ${ }^{2}$ MTA Központi Kémiai Kutatóintézet, Budapest
}

A talajokban az agyagásványok kedvező adszorpciós- és kationcserélö képességüknek köszönhetően kiemelkedő szerepet játszanak a fémion-körforgalmat érintő kémiai; duzzadásuk, diszperziós tulajdonságaik révén pedig a fizikai, vízgazdálkodási, szerkezetképző, degradációs stb. folyamatokban (NEMECZ, 1973). Mindazonáltal a talajban lejátszódó folyamatok, a fizikai-kémiai változások kisebb vagy nagyobb mértékben visszahatnak a talaj komponenseinek adszorpciós tulajdonságaira is. A talajalkotók érzékenysége e változásokra fokozottan igaz az agyagásványokra. Egyedi kristályszerkezeti és kristálykémiai jellemvonásaik miatt az agyagásványok talajokban leginkább ásványtanilag nem egyértelmüen definiálható formában vannak jelen. Ezek az egyedi jellemzők a következők: rendkívül kicsi szemcseméret, széles határon belül változó kémiai összetétel, az izomorf kémiai helyettesítésböl származó rétegtöltés, annak nagysága, eredete, valamint eloszlása az agyagkrisztallitokon belül, a szerkezeti rendezetlenség, két vagy több agyagásvány közberétegződése, valamint a kristályrács duzzadóképessége. Ezen anyagi tényezők mindegyikével számolni kell a talajainkban előforduló legközönségesebb duzzadó agyagásvány, a montmorillonit esetében. Napjainkra már számos tanulmány alátámasztotta, hogy az agyagásványok közül általában - éppen a fenti paramétereknek köszönhetően - a legjobb adszorpciós képességgel a szmektit-csoport ásványai rendelkeznek (HELIOS-RYBICKA et al., 1995; SHUKLA, 2000 és mások).

Bár a montmorillonitok szerkezeten (kristályrácson) belüli duzzadásának közvetlen okai máig vitatottak, a különböző álláspontok abban megegyeznek, hogy a montmorillonitrács izomorf helyettesítéseiből származó rétegtöltésében keresik a magyarázatot. Rendkívüli esetektől eltekintve általában igaz, hogy a duzzadóképesség csökken a rétegtöltés növekedésével (SUQUET et al., 1975). Ilyen kivétel, amikor egyes kis méretü kationok hő hatására beépülnek a montmorillonit oktaéderes kristálytani pozíciójába, s ezáltal semlegesítik a rétegtöltést és csökkentik a duzzadóképességet (MADEJOVÁ et al., 1999; NÉMETH, 2003). Vitán felüli azonban az a megállapítás, hogy az agyagásványok duzzadása a talaj vízáteresztő képességének egyik legfontosabb tényezője, ugyanis lineáris összefüggés áll fenn a talaj duzzadása és hidraulikus vezetőképessége között (MCNEAL et al., 1968).

Postai cím: NÉMETH TIBOR, MTA Geokémiai Kutatóintézet, 1112 Budapest, Budaörsi út 45.E-mail: ntibi@geochem.hu 
Hazai talajból származó montmorilloniton végzett fémion-adszorpciós vizsgálataink legföbb célja annak feltárása volt, hogy okozhat-e fémion-terhelés olyan változásokat a talajmontmorillonit kristályszerkezetében - elsősorban a szerkezeten belüli duzzadásában -, melyek kihatnak az egész talaj kémiai és fizikai tulajdonságaira.

\section{Anyag és módszer}

\section{Vizsgálati módszerek}

A minta $400 \mathrm{mg}$-os adagjait a $20 \mathrm{mg} / \mathrm{l}$-től $2000 \mathrm{mg} / \mathrm{l}$-ig terjedő tartományban tíz különböző koncentrációjú, egyenként 40 ml-nyi réz-szulfát, ólom-nitrát, illetve kadmium-nitrát oldattal reagáltattuk $50 \mathrm{ml}$-es zárt, müanyag centrifugacsövekben. $\mathrm{Az}$ adszorpciós kísérletek 48 óráig tartottak, úgy, hogy közben az agyagszuszpenziókat 24 órán át intenzíven ráztuk, hogy a folyamat biztosan elérje a közel teljes egyensúlyt. Laboratóriumi vizsgálatok bizonyították, hogy a Ca-montmorillonit teljes, a kationcsere kapacitással majdnem megegyező $\mathrm{Zn}^{2+}$-felvétele akár 15 perc alatt is végbemehet (BOURG \& FILBY, 1976). Számunkra nagyon lényeges, hogy az általunk alkalmazott kísérleti idő alatt akár már szerkezeti és kémiai változások is végbemehetnek a montmorillonitban. A kísérletek $25^{\circ} \mathrm{C}$-os hömérsékleten folytak. A szuszpenziók pH-ját $0,1 \mathrm{~N}$ kénsavval (a réz-szulfát esetében), illetve salétromsavval (a nitrátok esetében) 4,5-5 közötti pH-értékre igazítottuk, mert ebben a tartományban a legkisebb a fémionok megkötődésének pH-függése, továbbá a leggyengébb a $\mathrm{H}^{+}$-ionok kompetíciója más fémionokkal szemben az agyagásványok adszorpciós helyeiért (FARRAH \& PICKERING, 1979). A cserélődési kísérletek végén regisztráltuk a fémion-oldatok egyensúlyi $\mathrm{pH}$-ját. A fémion-oldatok kezdeti és a kicserélődési kísérletek végén tapasztalt egyensúlyi pH-ját Radelkis OP 211/1 típusú laboratóriumi digitális $\mathrm{pH}$-mérővel mértük.

A reakció után az agyagszuszpenziókban 20 perces centrifugálással 4000 fordulatszámon szétválasztottuk a szilárd fázist a folyadéktól. Az oldatban maradt fémion-koncentrációkat PerkinElmer 5000 atomabszorpciós spektrofotométerrel mértük. A kiindulási és a kísérlet után mért egyensúlyi koncentrációk közötti különbség adta a montmorillonit által megkötött fémionok mennyiségét.

A leválasztott szilárd fázist desztillált vízzel háromszor átmostuk. A röntgendiffrakciós vizsgálatokhoz minden minta azonos anyagmennyiségéből $\left(3,3 \mathrm{mg} / \mathrm{cm}^{2}\right)$ üveglemezre ülepített szuperorientált preparátumokat készítettünk. A preparátumokat közvetlenül a mérés megkezdéséig exszikkátorban állandó, alacsony és mindvégig ellenőrzött relatív páratartalom (25-30\%) alatt tartottuk, kiküszöbölendő a duzzadó montmorillonitok vízadszorpciójából eredő hibákat a szerkezetvizsgálatok során. A minták etilén-glikolos és glicerines telítése a megfelelő szolvatáló anyag gőzében történt, rendre 60 , ill. $95^{\circ} \mathrm{C}$-on 16 órán keresztül. A röntgendiffrakciós vizsgálatokat PHILIPS PW 1730 készüléken végeztük $\mathrm{Cu} \mathrm{K}_{\alpha}$ sugárzással, grafit monokromátor alkalmazásával $45 \mathrm{kV}$ gyorsítófeszültség és $35 \mathrm{~mA}$ csőáram mellett. Az alkalmazott divergencia- és detektorrés $1^{\circ}$-os volt. A felvételek $2-25^{\circ} 2 \Theta$ tartományban készültek, $0,02^{\circ} 2 \Theta$ lépésközönként 2 másodperces beütési idővel. 
A szmektit rétegtöltését alkil-aminos módszerrel határoztuk meg LAGALY (1994) leírását követve. A kationcserélő kapacitás meghatározása a módosított Mehlich-féle eljárással történt (RÉDLYNÉ, 1988). A vizsgált talajminta kémhatását 1:2,5 arányú desztillált vizes szuszpenzióban, elektrometriásan vizsgáltuk (MSz 21470/2-81, 1982).

\section{A talajmontmorillonit jellemzése}

Az adszorpciós vizsgálatokban felhasznált talajagyagminta miocén slíren képződött agyagbemosódásos barna erdőtalaj (FAO osztályozás alapján Haplic Luvisol; DRIESSEN et al., 2001) szelvényből származik, a cserháti Kisbárkány falutól 200 m-re keletre egy tölgyesből. A minta a szelvény 105-112 cm-es mélységét képviseli, mely egy meglehetősen agyagos, szürkésbarna (7,5YR5/2), a genetikai $\mathrm{B}_{\mathrm{t}}$-szintnek megfelelö réteg.

A teljes talajminta uralkodó ásványa a kb. 50\%-nyi kvarc, de igencsak figyelemre méltó már a teljes talajminta közel $40 \%$-os montmorillonit-tartalma is. A további ásványos alkotók mennyisége alárendelt. A montmorilloniton kívül az agyagásványokat nagyjából 5\%-nyi 10 Å-ös rétegszilikát (csillám, illit), valamint alig százalékos arányban klorit és/vagy kaolinit képviseli. A földpáttartalom 7\%, több plagioklásszal, kevesebb káliföldpáttal. Az agyagfrakció 80-85\% montmorillonitot tartalmaz. Mellette $10 \%$ illit, $5 \%$ kvarc és nyomokban kaolinit van jelen. A minta pH-ja 4,84, kationcserélö képessége $56 \mathrm{cmol} / \mathrm{kg}$.

Az 1. ábrán láthatóak a vizsgált talajagyag diffraktogramjai a különböző diagnosztikai kezelések után. A kezeletlen montmorillonit 14,8 Å-ös bázistávolsága $\mathrm{Ca}^{2+}$ és $\mathrm{Mg}^{2+}$ rétegközi kationok jelenlétére utal. Az alkil-aminos meghatározás

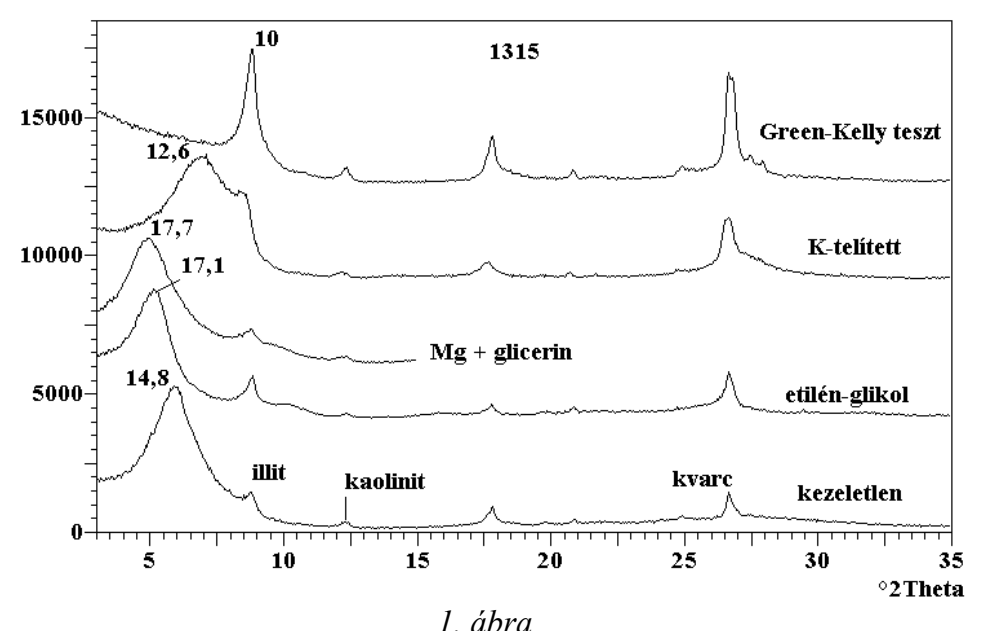

A talaj $2 \mu \mathrm{m}$ alatti frakciójáról készült diffraktogramok a különböző diagnosztikai kezelések után 
alapján a montmorillonit átlagos rétegtöltése 0,325 , minimum töltése 0,26 , maximum töltése pedig 0,39 fél elemi cellánként. A rétegközi töltés eloszlása az egymást követő 2:1 rétegszilikát egységek között heterogén jelleget mutat. A szmektitek körében az inhomogén töltéseloszlás egyáltalán nem ritka jelenség és különösen jellemző a különböző talajszmektitekre (LAGALY et al., 1976). A rétegtöltés viszonylag kis mértékét erősíti meg, hogy a montmorillonit rácsa káliumtelítés hatására csak 12,6 Å-re esik össze. A Green-Kelly teszt alapján ez a rétegtöltés kizárólag oktaéderes helyettesítésből származik, ami megerösíti, hogy a szmektit valóban montmorillonit. A 060 reflexió $1,50 \AA$ Aös poziciója egyértelmüen a dioktaéderes szmektitek csoportjába sorolja a vizsgált agyagásványt. A montmorillonit mind etilén-glikol, mind magnéziumtelítés és glicerin szolvatáció után a közönséges montmorillonitoktól megszokott módon rendre 17,1, ill. 17,7 Å-re duzzad.

Összegzésként elmondható, hogy a vizsgált talajagyag egy tipikus, heterogén töltéseloszlású, kis rétegtöltésủ montmorillonit, amely hazai agyagos talajaink közönséges alkotója, sőt egyik uralkodó agyagásványa.

\section{Eredmények és értelmezésük}

\section{A talajmontmorillonit fémion-adszorpciója}

A 2. ábrán láthatóak a montmorillonit különböző fémionokra felvett adszorpciós izotermái. GILES és munkatársai (1960) osztályozásában a réz- és ólomadszorpciós izotermák alakja inkább a $\mathrm{H}$ típusú görbékéhez, a kadmium izoterma alakja az L típusú görbéhez áll közelebb. A pozitív töltésü ionok szorpciója agyagásványokon általában hasonló görbéket eredményez, utalva a negatív töltésủ agyagásványok nagy affinitására a kationokhoz (FILEP, 1988). A réz és a kadmium adszorpciója a legkisebb kiindulási koncentrációnál $(20 \mathrm{mg} / \mathrm{l})$ a legnagyobb $(85 \%$, ill. 89,6\%). A

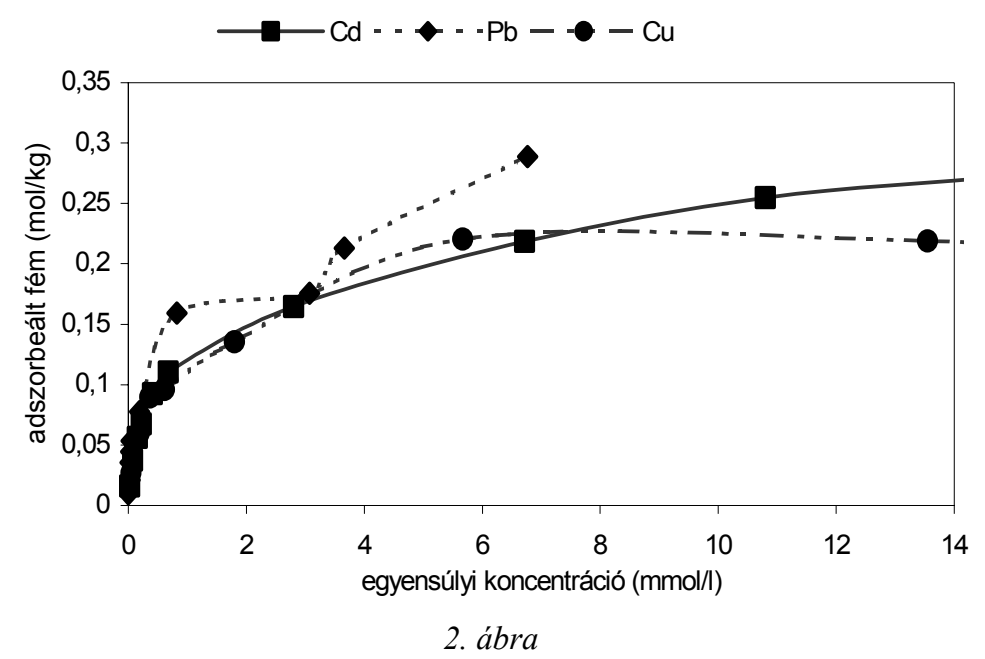

A talajmontmorillonit különböző fémionokra felvett adszorpciós izotermái 
megkötött fémion arány a koncentráció növekedésével fokozatosan csökken. 2000 mg/l-es koncentrációjú oldatból már csak a réz 7,8\%-a, a kadmiumnak pedig

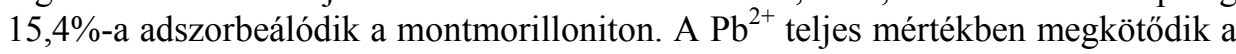
$20 \mathrm{mg} / \mathrm{l}$-es oldatból, azonban egy újabb 92,5\%-os fajlagos adszorpciós maximum figyelhető meg a 80 és $100 \mathrm{mg} / \mathrm{l}$-es kiindulási oldatnál, pH 6,4 és 5,7 értéken. Ebben a pH- és koncentrációtartományban az adszorbátum koncentrációja már kellően nagy, a $\mathrm{H}^{+}$-ion kompetíciója pedig már eléggé kicsi ahhoz, hogy maximális legyen a borítottság. DE LA FLOR és munkatársai (1995) ezzel összhangban azt figyelték meg, hogy a réz adszorpciója 6,5 pH-értéken maximális. A réz- és kadmiumadszorpció során az egyensúlyi $\mathrm{pH}$ fokozatosan csökken a kiindulási és az egyensúlyi koncentrációk növekedésével. Ólom esetében a kezdeti savasodás után a 80 $\mathrm{mg} / \mathrm{l}$-es kiindulási koncentrációjú oldatban enyhe lúgosodás tapasztalható $(\mathrm{pH}=$ 6,38), amelyet aztán az előbbiekhez hasonlóan szintén savasodás követ. A pH csökkenése a fémionok hidrolízisének és a már adszorbeálódott kationok koordinációs vízmolekuláiból felszabaduló protonoknak tudható be (FARRAH \& PICKERING, 1979).

Bár montmorillonitokra kevésbé teljesülnek a Langmuir-féle izotermaegyenlet azon feltételei, hogy az adszorpció sík felületen megy végbe, hogy az adszorpciós helyek egyenértékủek, továbbá, hogy az adszorpció reverzibilis; a vizsgált fémionok adszorpciója mégis 95\%-os biztonsággal linearizálható a Langmuir-féle izotermaegyenlettel. Az egyenletböl számolt maximális adszorpciós értékeket az 1. táblázat mutatja. A maximális adszorpciós kapacitásértékek összevethetők több kutató eredményeivel: VENGRIS és munkatársai (2001) például rézre $83300 \mathrm{mg} / \mathrm{kg}$ értéket kaptak aktivált agyagon. NASEEM és TAHIR (2001) vizsgálatai szerint 52630 mg ólom adszorbeálódik egy kilogramm bentoniton. Szintén a Cserhátból származó talajvermikulit $48000 \mathrm{mg} / \mathrm{kg}$ ólmot kötött meg, ami azt mutatja, hogy a montmorilloniton kívül más agyagásványok is képesek nagy mennyiségben adszorbeálni az ólmot (SIPOS et al., 2005).

$\mathrm{Az}$ egyionos adszorpciós kísérletek alapján a fémionok affinitása a vizsgált talajmontmorillonit felé a $\mathrm{Cd}>=\mathrm{Pb}>\mathrm{Cu}$ sorrendet követi. Ez a sorrend nagyjából megfelel a fémionok hidratációs entalpia sorrendjének, amennyiben a kisebb hidratációs entalpiájú $\mathrm{Cu}^{2+}$ nagyobb hidrátburka miatt gyengébben kötődik meg (3. ábra).

\section{1. táblázat}

A talajmontmorillonit Langmuir-egyenlet alapján számított maximális adszorpció értékei a vizsgált fémionokra

\begin{tabular}{|c|c|c|c|}
\hline \multirow{2}{*}{ Maximális adszorpció } & \multicolumn{3}{|c|}{ (2) Adszorbeált fémion } \\
\cline { 2 - 4 } & $\mathrm{Cu}$ & $\mathrm{Cd}$ & $\mathrm{Pb}$ \\
\hline $\mathrm{mol} / \mathrm{kg}$ & 0,233 & 0,277 & 0,269 \\
$\mathrm{mg} / \mathrm{kg}$ & 14795 & 31135 & 55737 \\
\hline
\end{tabular}




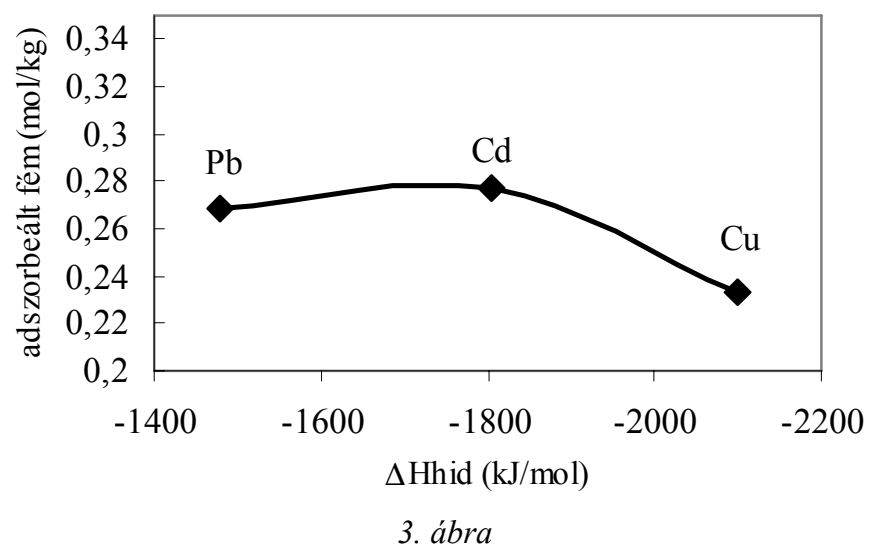

Összefüggés a fémionok hidratációs entalpiája és a talajmontmorillonit által megkötött maximális fémion-koncentráció között (entalpiaadatok forrása: BURGESS, 1978)

\section{A fémion-adszorbeált talajmontmorillonit röntgendiffrakciós vizsgálata}

A 4. ábrán láthatóak a különböző fémion-koncentrációkkal kezelt fémionadszorbeált montmorillonitok diffraktogramjai. A kezdeti 14,5 § körüli rétegtávolság a 20-150 mg/l hozzáadott rézkoncentráció-tartományban végig fennmarad. 200 $\mathrm{mg} / 1$ hozzáadott rézkoncentrációtól kezdve, 4,51-es egyensúlyi $\mathrm{pH}$ mellett azonban felfedezhető egy $13 \AA$ körüli váll a rézadszorbeált montmorillonit diffraktogramján. Ha a kiindulási rézkoncentrációt még tovább emeljük addig amíg az adszorpciós izotermán jól nyomon követhető módon a montmorillonit már megközelítőleg eléri a maximális rézfelvételt, a montmorillonit bázisreflexiója egyértelmüen nagy $2 \Theta$ szögek felé tolódik. Állandósul egy 12,5-13 Å körüli bázistávolság, amely jól öszszeegyeztethető a szakirodalom túlnyomó részében közölt 12,5 Å körüli bázisreflexió értékkel (PUSINO et al., 1989; EMMERICH et al., 2001). Ez a bázistávolság a rétegközi térben adszorbeált réz egy rétegvizes elrendezésére utal, ami általában az egyértékű kationok sajátsága. A diffraktogramok és az adszorpciós izotermák öszszevetéséböl megállapítható, hogy a montmorillonit rézzel telítődött, az ioncsere teljesen végbement és a Cu-montmorillonitokra jellemző, egy vízrétegü, 12,5 rácstávolságú szerkezet jött létre.

A 20-200 mg/l ólomkoncentráció-tartományban 5,62-5,22 pH között a kiindulási $15 \AA ̊$-ös bázistávolság mindvégig megőrződik. $500 \mathrm{mg} / 1$ hozzáadott $\mathrm{Pb}^{2+}$ esetében $(\mathrm{pH}=5,05)$ a bázisreflexió szélesedik és maximuma 14,2 A-re tolódik. Efölötti koncentrációtartományban és savasabb pH-értéken a bázistávolság már egyértelmüen $13 \AA$ körüli, utalva arra, hogy az ólom egy vízrétegü alakban található a rétegközi térben. BRIGATTI és munkatársai (1995) 12,4 Å-ös bázistávolságot figyeltek meg Ca-montmorilloniton végzett ólomadszorpciós kísérletük végeredményeként. Interpretációjukban a 13-14 § körüli értékek a kis koncentrációtartományban ólomra lecserélt és még lecseréletlen, változatlan rétegek közberétegzésének tulajdoníthatók. 


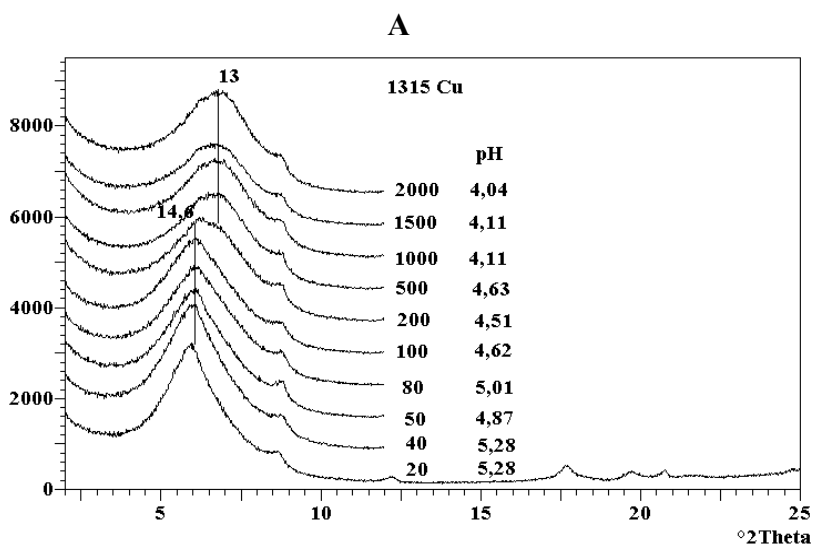

B

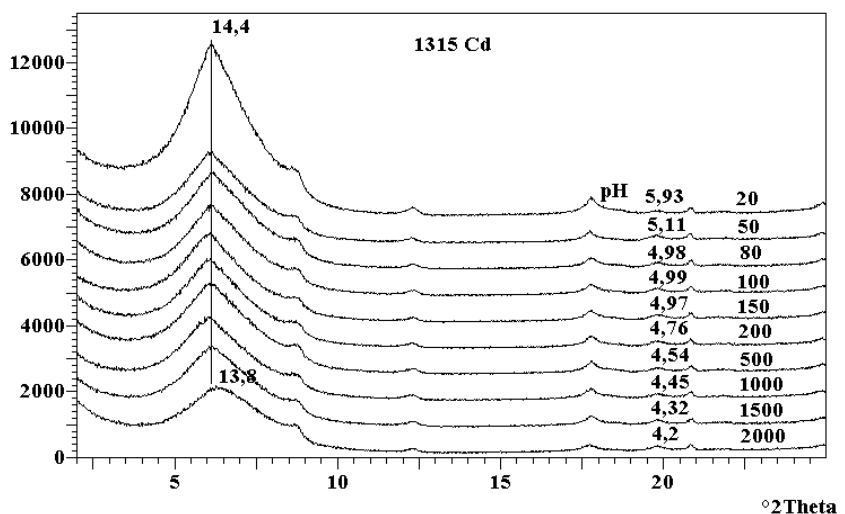

C

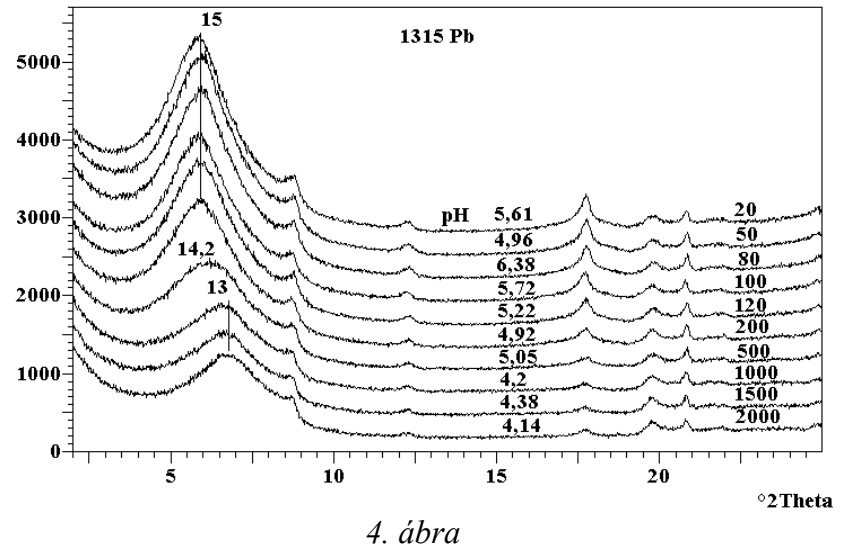

A réz (A), kadmium (B) és ólom (C) fémionokkal adszorbeált talajmontmorillonitról készült röntgendiffraktogramok 
A legkevésbé szembetünő a kadmium-adszorpció hatása az eredeti talajmontmorillonit kristályszerkezetére. A kiindulási montmorillonit 14,4 Å-ös bazális rácssíktávolsága a $2000 \mathrm{mg} / \mathrm{l}$-es minta kivételével a teljes koncentrációtartományban (5,93-4,2 pH-tartományban) érvényes marad. Csak a legnagyobb kadmium-terhelés $(2000 \mathrm{mg} / \mathrm{l})$ okozott csekély mértékü eltolódást a bázisreflexió pozíciójában nagy $2 \Theta$ szögek irányába. Ezek alapján a vizsgált talajmontmorillonit rétegközi terében adszorbeált $\mathrm{Cd}^{2+}$ kétrétegü hidratált formában fordul elő.

\section{A fémion-adszorbeált talajmontmorillonit szerkezeti duzzadása}

A montmorillonit kristályrácson belüli duzzadóképességének megmaradását vagy változását az adszorpció során szerves reagensekkel ellenőriztük. Mivel a duzzadóképesség nem annyira az adszorbátum - egyedüli feltétel, hogy a molekula poláros természetü és ne túl nagy méretü legyen -, hanem az agyagásvány rétegközi töltésének és kationjának függvénye, az eredmények extrapolálhatók a talajoldatban előforduló komponensekre, talajvízre, és modellértékűek számos szerves anyagra is. Mindezek mellett azért választottuk a fémion-adszorbeált montmorillonitok és az etilén-glikol, illetve a glicerin közötti kölcsönhatás vizsgálatát, mert a mindennapi gyakorlatban e kettő alkoholt használják a duzzadó agyagásványok meghatározására, elkülönítésére.

$\mathrm{Az}$ etilén-glikolos kezelés után mindhárom fémion-adszorbeált montmorillonit 17 Å-ös bázistávolsággal és a magasabb rendű reflexiók nagyjából integrális sorozatával jellemezhető. Ez azt sugallja, hogy - legfeljebb a legnagyobb koncentrációk kivételével - csaknem minden esetben olyan homogén, kétrétegü etilén-glikolmontmorillonit komplex jött létre, mely általában jellemzö a szmektitekre (5. ábra). A kezeletlen és a kezelt montmorillonitok bázistávolsága között nem tapasztalható lényeges különbség. Mindazonáltal közös jellemvonás, hogy a (001) csúcs magassága csökken, félérték-szélessége pedig növekszik a mintához adott fémionok koncentrációjával. Az ólomadszorbeált minta esetében figyelhető meg leginkább a vonalprofil ilyetén alakulása. Ez valószínüleg azzal magyarázható, hogy a nagyobb koncentrációtartományban már lehetséges egy-egy olyan réteg közberétegződése a montmorillonit szerkezetben, mely már nem képes teljes mértékben szolvatálódni.

Glicerinezés után kis rézkoncentrációk mellett a montmorillonit a kezeletlen formájára utaló 18 Å körüli bázistávolságot mutatja. $100 \mathrm{mg} / \mathrm{l} \mathrm{hozzáadott} \mathrm{réz} \mathrm{eseté-}$ ben azonban a glicerin hatására a montmorillonit már csak $16 \AA$ körülire duzzad, sőt a 001 csúcs mellett a röntgendiffraktogramon megjelenik egy határozott váll 14,2 Å környékén. A rézkoncentráció további növekedésével a 16 Å-ös széles csúcs maximuma egyre inkább a 14,2 A-ös váll felé tolódik, annyira, hogy $1000 \mathrm{mg} / \mathrm{l}$ hozzáadott rézkoncentrációnál és a fölött már csak egy határozott 14,2 Å-ös reflexióval jellemezhető a montmorillonit (5. ábra). Mindez arra utal, hogy a kezdetben a rétegközi terükben két glicerinréteget tartalmazó $18 \AA$ bázistávolságú egységek közberétegződnek olyan rétegekkel, melyek már csak egy glicerinréteget képesek a rétegközi terükbe fogadni, létrehozva a $16 \AA$ Åazális rácssíktávolságú köztes állapotot, végső esetben pedig a 14,2 $\AA$ vastag egyrétegü komplexet. Hasonló közberétegzés megléte különbözö hidratáltsági fokú szmektit egységek között már 1940 

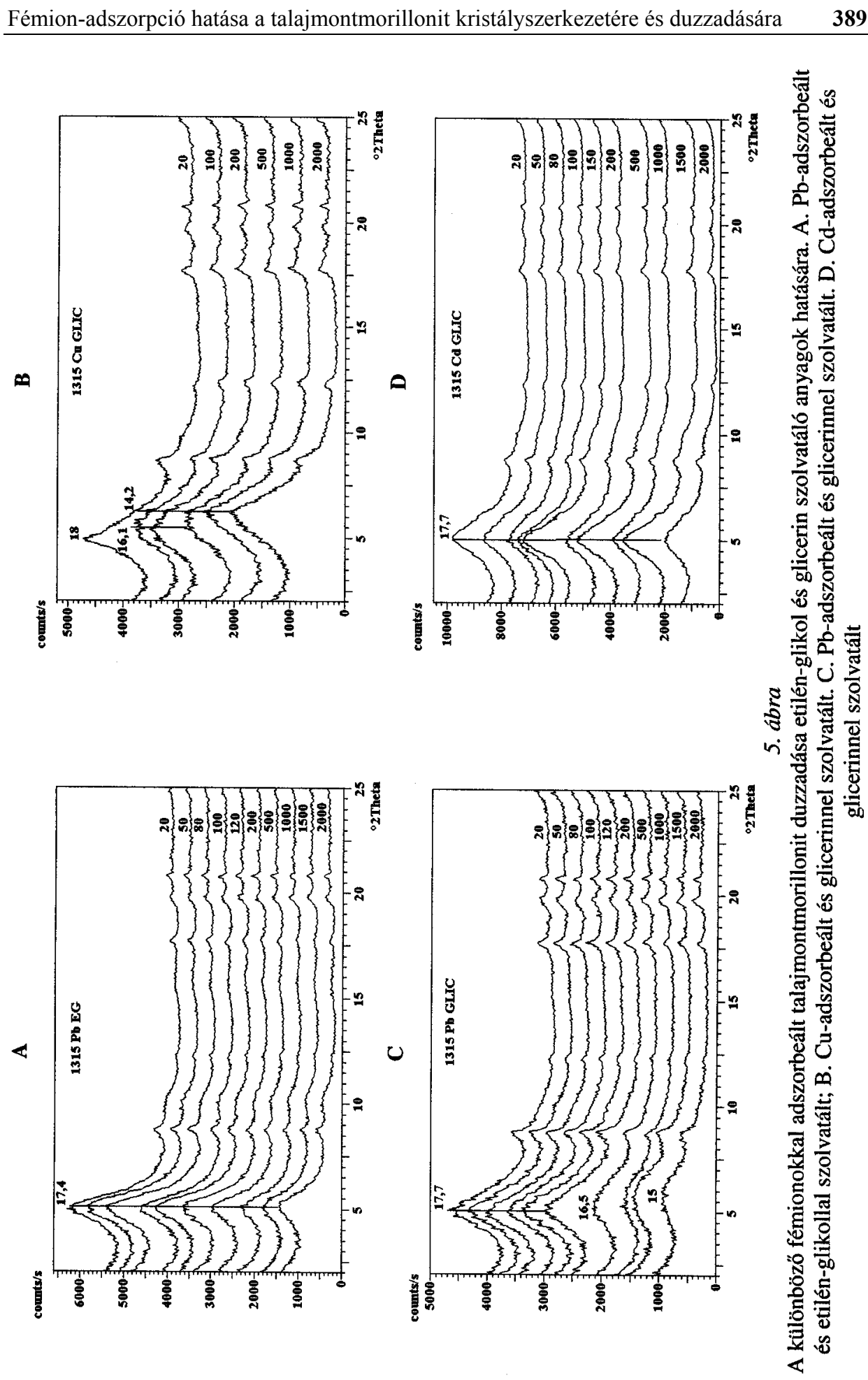
óta ismert és bizonyított. Újabban WU és munkatársai (1997) a két- és háromrétegü hidrátok között írnak le 15-17,5 ^ körüli reflexiót tanúsító kevert szerkezetet. Nagy tisztaságú montmorillonitokon végzett részletes kristálykémiai és rácstágulási vizsgálatok, továbbá rétegtöltésmérések sugallták azt a feltételezést, hogy heterogén töltéseloszlású montmorillonitokban a kis méretü $\mathrm{Cu}^{2+}$ szilikátvázba történő beépülése semlegesíti a rétegtöltést, s ezáltal duzzadásvesztést okoz (NÉMETH, 2003). Glicerin esetében is általánosan megfigyelhető az intenzitás csökkenése, mely az etilén-glikolozáséhoz hasonló okokkal magyarázható.

A röntgendiffraktogram-sorozaton jól nyomon követhető, hogy a kiindulási és a kisebb ólomterhelésủ mintákra jellemző 18 Å-ös bázisreflexió $200 \mathrm{mg} / \mathrm{l}$ hozzáadott ólomkoncentráció felett 16,5, majd $15 \AA \AA$-re csökken. Csakúgy ahogy a rézadszorbeált minta, az ólommontmorillonit is elveszti tehát duzzadóképességét, amennyiben kettő helyett csak egy réteg glicerint képes a rétegközi terébe építeni. Ebben az esetben azonban a duzzadóképesség-csökkenés hátterében az állhat, hogy a nagyméretű $\mathrm{Pb}^{2+}$ szorosan beilleszkedik a hatos szilikáttetraéder gyürükbe, melynek következtében összeomlasztja és stabilan tartja a szerkezetet. Végül ez a duzzadóképesség, illetve - ahogy azt AUBOIROUX és munkatársai (1996) vizsgálatai feltárták - a kationcserélő képesség csökkenését eredményezi. Ez a hatás hasonló a káliumionéhoz. Az azonosság tükrözödik a káliumtelített $(12,6 \AA$ ) és az ólomadszorbeált (13 $\AA$ ) talajmontmorillonit közel egyforma rácssíktávolságában is.

Hasonlóan az etilén-glikollal kapcsolatban tapasztaltakhoz, a glicerin-szolvatáció is teljes mértékben végbemegy a kadmium-adszorbeált minta esetében. A talajmontmorillonit rácsa a szmektitekre általánosan jellemző módon 17,7 ̊̊ körüli értékre tágul (5. ábra). A többi fémionnal ellentétben a kadmiumion tehát nem befolyásolja a vizsgált talajmontmorillonit duzzadóképességet. $\mathrm{A} \mathrm{Cd}^{2+}$-ion nagyobb, mint a $\mathrm{Cu}^{2+}$-ion, azonban kisebb az $\mathrm{Pb}^{2+}$-ionnál, azaz az előbbiekben vázolt két duzzadásvesztési mechanizmus egyike sem tud megvalósulni. Nagy ionrádiusza miatt a $\mathrm{Cd}^{2+}$ nem képes beépülni a montmorillonitrács oktaéderes pozícióiba; ahogy a káliumionhoz vagy ólomionhoz hasonló összetartó erőt sem fejt ki a rétegek között a hatos tetraédergyürük felett.

\section{Összefoglalás}

Talajmontmorilloniton végzett adszorpciós kísérleteink újabb adatokkal támasztották alá, hogy a montmorillonitok valóban nagy mennyiségben képesek fémionokat megkötni, s ezáltal rendkívül jelentős szerepük van a talajban lejátszódó kémiai folyamatokban, a nyomelemek és szennyezők talajbeli mozgásában.

A különbözö fémionokkal adszorbeált montmorillonit röntgendiffrakciós vizsgálata megerösítette azt a tényt, hogy a rétegközi kation természete alapjaiban befolyásolhatja a szmektitek legszembetünőbb szerkezeti vonását, a bázistávolságot. A $\mathrm{Cu}$ - és $\mathrm{Pb}$-adszorbeált montmorillonitok bazális rácssíktávolsága 12,5, ill. $13 \AA$ Á, mely a víz egyrétegű elrendeződésére utal a rétegközi térben. Ezzel szemben a $\mathrm{Cd}^{2+}$ a kétrétegü kationoknak megfelelő két vízrétegü formában adszorbeálódott a montmorillonit rétegközi terében. Az adszorbeált kation kémiai természetén felül 
egyértelmúen lényeges tényező ebben az is, hogy az adott fémion mekkora koncentrációban van jelen a montmorillonittal kölcsönhatásban lévő oldatban.

Glicerines kezelés után a $\mathrm{Cu}$ - és Pb-adszorbeált montmorillonit-minták duzzadásvesztést mutatnak, míg a kadmiumadszorpció nem változtatja meg a talajmontmorillonit duzzadóképességét. Az egyébként duzzadó vermikulitok megkülönböztető sajátsága az, hogy viszonylag nagy rétegtöltésüknek köszönhetően rétegközi terükbe csak egy glicerinréteget képesek magukba fogadni, mert a 2:1 szilikát egységeket összekapcsoló erő meghaladja a szmektitekét. A vizsgált montmorillonit tehát nagyobb réz-, illetve ólomterhelésre nemcsak hogy elveszti kristályrácson belüli duzzadóképességét, de adott esetben fémmel szennyezett talajban könnyen félre is határozható vermikulitnak.

Kulcsszavak: fémion-adszorpció, montmorillonit, duzzadóképesség, talaj

\section{Irodalom}

Auboiroux, M. et al., 1996. Fixation of $\mathrm{Zn}^{2+}$ and $\mathrm{Pb}^{2+}$ by a Ca-montmorillonite in brines and dilute solutions: Preliminary results. Applied Clay Science. 11. 117126.

BouRG, A. C. M. \& FiLBY, R. H., 1976. Isotopic exchange of $\mathrm{Zn}^{65}$ with stable $\mathrm{Zn}$ adsorbed on reference clay minerals. Geochimica et Cosmochimica Acta. 40. $1573-1574$.

BRIGATTI, M. F. et al., 1995. Interaction between montmorillonite and pollutants from industrial waste-waters: exchange of $\mathrm{Zn}^{2+}$ and $\mathrm{Pb}^{2+}$ from aqueous solutions. Applied Clay Science. 9. 383-395.

BURGESS, J., 1978. Metal Ions in Solution. Ellis Horwood. Chichester.

DE LA Flor, M., Vigil DE LA VILLA, R. \& CALA, V., 1995. Copper sorption in clay fractions of alluvial soils. The Science of the Total Environment. 172. 245-249.

DriesSEN, P. et al., 2001. Lecture Notes on the Major Soils of the World. World Soil Resources Report. FAO. Rome.

EMmerich, K., PlötZe, M. \& KAHR, G., 2001. Reversible collapse and $\mathrm{Mg}^{2+}$ release of de- and rehydroxylated homoionic cis-vacant montmorillonite. Applied Clay Science. 19. 143-154.

FARRAH, H. \& PICKERING, W. F., 1979. pH effects in the adsorption of heavy metal ions by clays. Chemical Geology. 25. 317-326.

FiLEP Gy., 1988. Talajkémia. Akadémiai Kiadó. Budapest.

Giles, C. H., MacEwan, T. H. \& Smith, D., 1960. Studies in adsorption. Part XI. Journal of Chemical Society. 10. 3973-3993.

Helios Rybicka, E., Calmano, W. \& BreEger, A., 1995. Heavy metals sorption/desorption on competing clay minerals; an experimental study. Applied Clay Science. 9. 369-381.

LAGALY, G., 1994. Layer charge determination by alkylammonium ions. In: Layer Charge Characteristics of 2:1 Silicate Clay Minerals. (Ed.: MERMUT, A. R.) CMS Workshop Lectures. 6. 1-47. 
Lagaly, G., Fernandez GonZalez, M. \& Weiss, A., 1976. Problems in layer-charge determination of montmorillonites. Clay Minerals. 11. 173-187.

Madejová, J., Arvaiová, B. \& Komadel, P., 1999. FTIR spectroscopic characterization of thermally treated $\mathrm{Cu}^{2+}, \mathrm{Cd}^{2+}$, and $\mathrm{Li}^{+}$montmorillonites. Spetrochimica Acta. A 55. 2467-2476.

MCNEAL, B. L. et al., 1968. Factors influencing hydraulic conductivity of soils in the presence of mixed-salt solutions. Soil Sci. Soc. Amer. Proc. 32. 187-190.

MSz 21470/2-81. 1982. Környezetvédelmi talajvizsgálatok. Talajminta elökészítése, nedvességtartalom, elektromos vezetés és pH meghatározása. Magyar Szabványügyi Hivatal. Budapest.

NASEEM, R. \& TAHIR, S. S., 2001. Removal of Pb(II) from aqueous/acidic solutions by using bentonite as an adsorbent. Water Research. 35. 3982-3986.

NEMECz E., 1973. Agyagásványok. Akadémiai Kiadó. Budapest.

NÉMETH T., 2003. Montmorillonitok fémion-adszorpciójának kristályszerkezeti, kristálykémiai és ásványtani vonatkozásai. Doktori értekezés. Eötvös Loránd Tudományegyetem Természettudományi Kar. Budapest.

Pusino, A. et al., 1989. Interaction of diclofop-methyl with $\mathrm{Al}^{3+}-, \mathrm{Fe}^{3+}-$, and $\mathrm{Cu}^{2+}-$ saturated montmorillonite. Clays and Clay Minerals. 37. 558-562.

RÉDLY L.-NÉ, 1988. A talajok kationcserélő kapacitásának meghatározása módosított Mehlich-módszerrel. In: Talaj- és agrokémiai vizsgálati módszerkönyv 2. (Szerk.: BuZÁs I.) 116-117. INDA 4231 Kiadó. Budapest.

SHUKLA, L. M., 2000. Sorption of zinc and cadmium on soil clays. Agrochimica. 44. 101-106.

SIPOS, P. et al., 2005. Effect of soil composition on adsorption of lead as reflected by a study of natural forest soil profile. Geoderma. 124. 363-374.

Suquet, H., CAlle, C. DE LA \& Pezerat, H., 1975. Swelling and structural organization of saponite. Clays and Clay Minerals. 23. 1-9.

Vengris, T., BINKIENĖ, R. \& SVEIKAUSKaité, A., 2001. Nickel, copper and zinc removal from waste water by a modified clay sorbent. Applied Clay Science. 18. 183-190.

WU, T. C. et al., 1997. Montmorillonite under high $\mathrm{H}_{2} \mathrm{O}$ pressures: Stability of hydrate phases, rehydration hysteresis, and the effect of interlayer cations. American Mineralogist. 82. 69-78.

Érkezett: 2005. december 19. 


\title{
Effect of $\mathrm{Cu}, \mathrm{Pb}$ and $\mathrm{Cd}$ Ion Adsorption on the Crystal Structure and Intracrystalline Expansion of Soil Montmorillonite
}

\author{
${ }^{1}$ T. NÉMETH, ${ }^{1}$ P. SIPOS, ${ }^{1}$ M. TÓTH and ${ }^{2}$ I. MOHAI \\ ${ }^{1}$ Institute for Geochemical Research, Hungarian Academy of Sciences, Budapest and \\ ${ }^{2}$ Institute of Materials and Environmental Chemistry, Chemical Research Center, \\ Hungarian Academy of Sciences, Budapest
}

\begin{abstract}
Summary
The effect of $\mathrm{Cu}, \mathrm{Pb}$ and $\mathrm{Cd}$ adsorption on the crystal structure and intracrystalline expansion of a soil montmorillonite was examined. The studied sample was a characteristic low charge montmorillonite with heterogenic charge distribution from the B horizon of a Haplic Luvisol profile from the Cserhát Hills in NE Hungary.

The adsorption of the studied metal ions could be described by the Langmuir equation. The affinity of the metals to the soil montmorillonite was as follows: $\mathrm{Cd} \geq \mathrm{Pb}>$ $\mathrm{Cu}$. This corresponds to the hydration enthalpy sequence of these metals. In the case of $\mathrm{Cu}$ and $\mathrm{Pb}$ adsorption the montmorillonite was saturated with metal ions and a onewater-layer montmorillonite was formed with a basal spacing of 12.5 and $13 \AA$, respectively. By contrast $\mathrm{Cd}^{2+}$ was adsorbed as two-water-layer form.

The change in the expansion capacity of montmorillonite adsorbed with metal ion was studied by ethylene-glycol and glycerol solvation. After the ethylene-glycol treatment a homogeneous ethylene-glycol-montmorillonite complex was formed in each case, which is characteristic of smectites, in general. At high added metal concentrations the interstratification of not completely solvated layers may be observed. This phenomenon is most characteristic of $\mathrm{Pb}$-montmorillonite.

After the glycerol treatment both $\mathrm{Cu}$ - and $\mathrm{Pb}$-montmorillonite had lost their expansion capacity. In the case of $\mathrm{Cu}$-montmorillonite this was because of the neutralization of the layer charge due to the entrapment of the small $\mathrm{Cu}^{2+}$ ions in the silicate structure, while in the case of $\mathrm{Pb}$-montmorillonite the entrance of the metal ion into the silicate tetrahedral rings caused the collapse of the crystal lattice. A similar effect can be observed during the K-saturation of swelling clay species, suggesting the same effect of these two large cations on the crystal structure.

By contrast with $\mathrm{Cu}$ and $\mathrm{Pb}$, the adsorption of $\mathrm{Cd}$ ions does not affect the expansion capacity of soil montmorillonite. The size of $\mathrm{Cd}^{2+}$ is between that of $\mathrm{Cu}^{2+}$ and $\mathrm{Pb}^{2+}$, so neither of the mechanisms mentioned above can take place.

The adsorption of metal ions in the interlayer space can influence the basal spacing of the smectite, and thus, also affects the physical and chemical properties of the soil. This effect must be taken into account when polluted soils are studied. Additionally it may cause clay mineralogical diagnostic problems as well.

Table 1. Maximum metal ion adsorption capacity of the soil montmorillonite calculated by the Langmuir equation. (1) Adsorbed metal ion. (2) Maximal adsorption.

Fig. 1. X-ray diffraction patterns of clay fractions of the studied soil after the different diagnostic treatments.

Fig. 2. Adsorption isotherms of the soil montmorillonite for the studied metal ions.
\end{abstract}


Fig. 3. Relation between hydration enthalpy and the maximum concentration of metal ions adsorbed by the soil montmorillonite (enthalpy values after BURGESS (1978)).

Fig. 4. X-ray diffraction patterns of soil montmorillonite after adsorbing metal ions. a) $\mathrm{Cu}$, b) $\mathrm{Pb}, \mathrm{c}) \mathrm{Cd}$.

Fig. 5. Expansion of the soil montmorillonite adsorbed with metal ions as the result of ethylene-glycol and glycerol salvation. a) Pb-montmorillonite solvated with ethyleneglycol; b) Cu-montmorillonite solvated with glycerol; c) Pb-montmorillonite solvated with glycerol; d) Cd-montmorillonite solvated with glycerol. 